\title{
Pleural Malignant Mesothelioma cM1 TNM Finding v8
}

National Cancer Institute

\section{Source}

National Cancer Institute. Pleural Malignant Mesothelioma cM1 TNM Finding v8. NCI

Thesaurus. Code C136383.

Pleural malignant mesothelioma with distant metastasis. (from AJCC 8th Ed.) 